Citation

Cintas, C., Héliot, Y. and Sprimont, P.-A. (2020), "Religious accommodation in France: decoding managers' behaviour", Employee Relations, Vol. ahead-of-print No. ahead-of-print. https://doi.org/10.1108/ER-02-2020-0050

\title{
Religious accommodation in France: decoding managers' behaviour
}

Abstract

\section{Purpose}

This research aims to explain, in the secular French context, the intention of managers to accommodate religious expression in the workplace (REW) when they are not obliged to do so. This paper seeks to understand the determinants of managerial positions on religious expression at work. Building on previous studies on how organisations and managers deal with religious expression, this research seeks to extend the evidence on this important aspect of managerial behaviour in relation to accommodating REW.

\section{Design/Methodology/Approach}

The hypotheses were tested using a structural equation model based on the theory of planned behaviour in diversity management ( $N=151$ French managers). This method highlights attitudinal and organisational determinants favourable to the intent to accommodate.

\section{Findings}

The present research provides new insight by identifying two main direct factors affecting managers' accommodation, namely, organisational flexibility (flexible hours, autonomy) and perceived consequences (advantages, disadvantages), and one indirect factor, religiosity. In line with the contradictions within diversity management, the perceived consequences are ambivalent and highly context dependent. One issue to explore is that managers seek to deal with religious expression by making it invisible.

\section{Research Implications}

In the French context, the explanatory social norm might not be "religiosity" but rather "perceived secularity". We recommend that future studies use qualitative methods with interviews and photo elicitation to extend this first study. Indeed, the complexity of the managerial position requires an in-depth understanding of managers' attitudes and behaviours with regard to religion. How do managers apply a common-ground strategy and create unity despite differences? Is the desire to make arrangements invisible with a view to inclusive neutrality specific to France, or can it be generalised to managers in other countries? Does the intention to accommodate not essentially depend on the manager-employee relationship dynamic? This research raises questions for scholars about the relationship with the other and ethical managerial conduct.

\section{Practical and Social Implications}

France is a secular country where a debate is emerging on cases of discrimination due to REW. The results contribute to approaches to drafting company guidelines for managers and may help organisations anticipate the risks associated with REW. The discussion of the results reveals the importance of social norms in the sense of hypernorms (religiosity) and undoubtedly of secularism, nondiscrimination, and gender equality in the decision-making process on 
accommodation. These inclusive norms should therefore be handled with care in the various guidelines that have been developed.

\section{Originality/Value}

REW is increasing but is a neglected dimension of diversity management. This study helps explore this new field by promoting an understanding of managers' intention to accommodate in a specific secular context.

Key words: Religious Accommodation, Managers, Theory of Planned Behaviour, Diversity Management, Religious Expression at Work (REW) 
Religious freedom is a fundamental freedom. This being so, some believers wish to live their religion on a daily basis, including at work. Prayer in the workplace and the wearing of religious symbols at work are examples of religious expression at work (REW). REW is the manifestation and externalisation of an employee's religious convictions. In recent years, REW has become more frequent and intense in European and North American companies (Cash and Gary, 2000, Morgan, 2004, King, 2008, Gebert et al., 2014, Bader et al., 2013). This phenomenon is increasingly observed in France (Observatoire Français du fait religieux 2014, 2015, 2016, 2017, 2018, and 2019). According to one report, in 2019, $70 \%$ of respondents were confronted with REW, and in $51 \%$ of cases, this REW required managerial regulation (Honoré, 2019).

This research focuses on the French context to address this issue. The WIN-Gallup survey (2015) shows that France is one of the most secularized countries in the world, with $37 \%$ of respondents claiming to be religious, and hosts the largest Jewish and Muslim communities in Europe. France is a secular republic. This principle is enshrined in its 1958 constitution. French secularism has an ambiguous characteristic that amplifies the controversy surrounding REW (Hennekam et al., 2018): it guarantees the freedom to believe or not to believe while protecting those who believe. This ambivalent legal framework leaves managers free to exercise their discretion (Hennekam et al., 2018). In this complex societal context, private organisations and their managers have to respond to new religious demands (Honoré, 2014).

Human resources (HR) departments have addressed this issue through constructing and implementing guidelines for managers. These tools provide a normative framework for regulating religious practices in companies. These guidelines, which are mainly found in large companies that must undertake diversity management, help managers make decisions. The tools are constructs specific to the values and standards adopted by each organisation, and they allow managers to interpret them freely according to the context. Apart from these tools, reflection 
and position taking with regard to the rise of REW are rare. Consequently, managers are confronted with two problems that are fundamental to any human group: the relationship to the other (with reference to individuals' religious difference) and living together (Chanlat, 2009). Given the decision-making latitude granted by French law and at a time when some companies are questioning the relevance of company policy and the implementation of guidelines and internal regulations to supervise REW (Cintas et al., 2013), it seems appropriate to attempt to understand managers' conduct with regard to REW. Both taking and not taking into account religious diversity in the workplace are problematic (Hennekam et al., 2018). Regulation of the consideration of religious diversity is complex. Such intervention depends both on the organisational context (human resources management culture and policy, available tools) and on the managerial stance towards religious expression in the company within the limits of regulatory constraints (labour law, internal regulations). Formal and consistent company policies and positions on the subject are still rare. The frequent absence of institutionalisation of management of religious issues in organisations leaves a great deal of responsibility and autonomy to local managers, who intervene and make decisions according to their representations of organisational and societal norms.

In terms of managerial behaviour, management of religious expression can differ. A previous study identified managers' positions towards and strategies for addressing REW ( Hennekam et al. 2018). Three managerial positions reflect managers' behaviour towards REW (Galindo and Zannad, 2014). Some, for example, refuse to allow REW. According to them, a company is not a place to practise or display one's religion (separation strategy). Other managers tolerate REW or try to create a strong corporate culture through a common-ground strategy. Alternately, some managers adopt a stance of accommodation (flexibility within the rules strategy). By neither accepting nor disallowing all REW, these managers aim to reconcile employees' requests with the general interest of the company by proposing adjustments. Hennekam et al. 
(2018) note that "while European countries do not have the obligation to reasonably accommodate for religion or belief, many managers actually do provide accommodation" (p.748). We believe it is essential to examine the reasons/determinants for this choice in greater depth. Therefore, in this paper, we will focus on the accommodation stance of managers to understand its determinants. Building on previous studies on how organisations and managers deal with religious expression (Mazumdar and Mazumdar 2005; Galindo and Surply, 2010; Galindo and Zannad 2014; Hennekam et al., 2018; Honoré, 2019), this research seeks to extend the results on the accommodation strategy managers adopt in responding to REW.

This subject is part of the human resources management axis of research on the place of religion in work settings (King, 2008). Its conceptual foundations are derived from the application of diversity management to explain managers' intention to manage religious diversity and the theory of planned behaviour (TPB) framework to explain the determinants of the decisionmaking process. Human resources management still neglects religious identity as part of diversity management in theory and practice (Tracey, 2012, Héliot et al., 2020). This research extends the existing literature in three ways. First, whereas the Anglo and Eastern contexts predominate in the international literature, this research focuses on the French cultural context to explain the accommodation stance towards REW. Second, it identifies some of the determinants at play in the managerial decision to opt for diversity management by adapting work situations. Finally, to the best of our knowledge, no prior research has attempted to explain managers' intention to accommodate REW.

\section{Literature Review}

\section{Theory of planned behaviour and diversity management}

The manager's decision-making process and his or her intention to accommodate or not to accommodate depends strongly on the French context with regard to religious diversity. The 
manager's decision and conduct have an ethical dimension. Fighting discrimination in this area and trying to be fair become the concerns of the manager in the context of diversity management. The TPB has been used in many management studies (Dawkins and Frass, 2005; Konopaske et al., 2009; MacCarthy et al., 2010; Chuang et al., 2015) and recently in studies dealing with diversity management in relation to disability (Araten-Bergman, 2016; Ang et al., 2015). We extend this application to the management of religious diversity.

\section{Theory of planned behaviour and intention to accommodate}

Explaining the intention to accommodate requires first clarifying the concepts of intention and accommodation. Behavioural intention in the TPB refers to the willingness to perform a behaviour (Azjen and Fishbein, 1980). The concept is crucially important because behavioural intention is considered the main predictor of behaviour (Giger, 2008).

This theory is based on the assumption that social behaviour is the result of people's willingness and judgement of a situation. In other words, before deciding to accommodate REW, the manager takes into account all the information at his or her disposal (e.g., guidelines, if they exist), examines the implications of the action for the functioning of the organisation and assesses the possible consequences. This behaviour is considered to be the product of reasoned, planned and controlled decision making (Giger, 2008). The individual (e.g., the manager) deliberates before acting (Ajzen and Fishbein, 2000).

The TPB proposes three determinants of behavioural intention (Ajzen, 1991): attitude, subjective norms and perceived behaviour control. The first determinant, attitude, is defined as the positive or negative assessment of whether the behaviour is accomplished (Azjen and Fishbein, 1980). Concerning the accommodation of REW, the manager will have beliefs about the consequences of his or her actions and will evaluate them. The assessment of the consequences of REW can be positive or negative overall and can influence the manager's decision making. The second determinant of intention is related to subjective norms. A 
subjective norm is related to the social pressure to accommodate the behaviour perceived by the manager. The third determinant of intention is perceived behavioural control, which reflects anticipation of obstacles or a lack of opportunities to achieve the intended behaviour (Ajzen 1987). In other words, the manager may want to accommodate but may be prevented from doing so because of a lack of opportunities and resources (i.e., because of the organisational context). Perceived behavioural control therefore complements motivational factors (attitudes and norms) by integrating a contingent dimension related to the organisational context. Thus, managers working in the same organisation and in the same situation will make different decisions according to their perceptions of their behaviour (attitude), their beliefs (subjective norms), and their organisational context (perceptions of opportunities and constraints). The TPB and the identified determinants help explain the behaviour. 
Figure 1: TPB applied to managers' accommodation behaviour in relation to REW

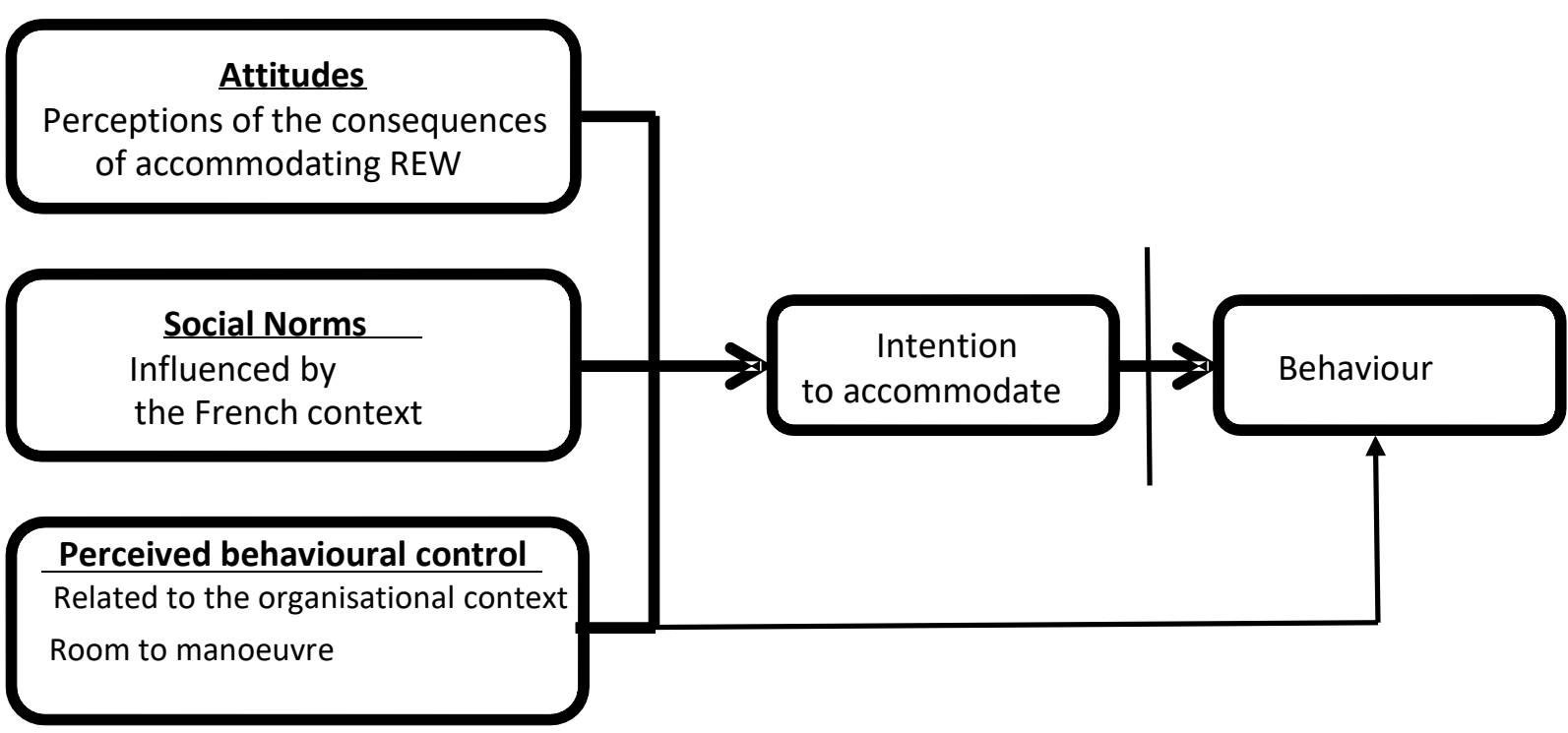

To understand the attitudes, social norms and perceived behavioural control of French managers, we must describe the French context in relation to diversity management and REW accommodation.

\section{Diversity management and religious accommodation}

The accommodation of work situations with regard to REW is based on diversity management (King, 2008). One of the challenges of diversity management is preserving equality. The concept of reasonable accommodation appeared in a European directive of 27 November 2000 on equal treatment in employment and occupation for people with disabilities (Adam and Rea, 2010). This European directive encourages an inclusive policy, i.e., an adaptation of existing mechanisms for the most diverse public possible to ensure equality. This reasoning is beginning to extend to religious minorities. 
In the United States, the Federal Anti-Discrimination Act (Title VII of the Civil Rights Act of 1964) in 1972 introduced the notion of "reasonable accommodation" in response to discrimination and cultural inequalities. It requires the employer to make reasonable accommodations with respect to the REW (Ludlum, 2016). In Europe and France, there is no concept of reasonable accommodation in the law. The Labour Code (2016 L1321-2-1) allows an employer to introduce provisions into its internal regulations establishing neutrality under certain conditions to limit the expression of employees' personal (and therefore religious) convictions. French law therefore gives managers a certain latitude in managing REW. This decision-making parameter is based on Article L. 1121-1 of the Labour Code: "No one may impose restrictions on the rights of individuals and on individual and collective freedoms that are not justified by the nature of the task to be performed or proportionate to the desired objective." Thus, if employees wish to organise a religious holiday within the company or request adapted working hours for religious practice, the Code provision specifies that it is up to management, within the framework of managerial power, to determine the response provided. The social climate and concern for balancing denominational demands are essential elements in the manager's decision to be more or less accommodating. Accommodation is defined here as the arrangement proposed by the manager in relation to the general rule of the organisation. This can be analogised to the flexibility within the rules strategy identified by Hennekam et al. (2018).

It is in this spirit of nondiscrimination and diversity that Inspiring More Sustainability (the IMS $)^{1}$ developed general guidelines in 2009 for the management of religious diversity. All the guidelines produced by large companies (e.g., EDF, Orange) mention the need to accommodate REW: "accommodation according to circumstances" for EDF and "reasonable accommodation,

\footnotetext{
${ }^{1}$ Created in 1986, IMS-Entreprendre pour la Cité is the umbrella organisation for a network of 200 companies. Its mission is to help its members incorporate into their CSR policies innovative social commitment measures that reflect both the challenges of their own development and the expectations of society at large. It was later renamed "Les entreprises pour la cité" (2016).
} 
compromise" for Orange. With or without these guidelines, the decision whether to accommodate is delegated to local managers (Observatoire du Fait Religieux, 2018, 2019; Galindo and Zannad, 2014; Hennekam et al., 2018).

The principle of justice on which accommodations are based is controversial in the context of French secularism.

\section{Focus on the context of French secularism}

French secularism advocates the separation of church and state (1905 law). The state is neutral; it does not recognise any religion but ensures the freedom of conscience of the citizen. The principle of secularism prohibits, during population censuses, the collection of individual data on religion (laws of 1872 and 1978). It is therefore difficult to provide a precise overview of religion in France. However, sociological studies show the decline of Catholicism and the emergence of a second religion, Islam (Pelletier, 2014). The Catholic-unbelieving stance that is at the centre of the history of French secularism is evolving towards a Catholic (5565\%)/Muslim (6-9\%)/No religion (23-32\%) triptych. The strikes of 1982 and 1983 in the automobile industry, which had a large Muslim immigrant workforce, were motivated by the practice of prayer in the workplace during break times (Pelletier, 2014). Although the Republic is secular, the evolution of society and companies in France is marked by its Christian history. Traditionally, the vast majority of companies adopt certain rites of the Christian religion (e.g., Sunday is the traditional weekly rest day; official holidays are sometimes Catholic religious holidays, such as Christmas, Easter, and Ascension). In this context, an increasing number of REWs come mainly from employees who practise Islam (Bader et al. 2013, Hunter-Henin, 2015; Killian, 2007; Bowen, 2004).

In this French societal context, private organisations and their managers must respond to new and sometimes complex religious demands (Honoré, 2014). 
Secularism provides for universal equality rather than equity: "the secular concern for equality does not lead to a request to extend the privileges of recognised religions to all others, but to cease these privileges in order to restore universal equality" (Pena-Ruiz, 2004, p. 65). In this conception, the accommodation advocated by diversity management is a form of recognition of REW. Thus, the fairness principle in the notion of reasonable accommodation coupled with the privileges accorded to recognised religions are in tension with each other. Therefore, preventing injustice through the management of religious diversity is not easy (Cintas et al., 2013).

The conceptualisation of managers' intention to accommodate through the TPB and diversity management allows us to formulate hypotheses and propose a theoretical model.

\section{Formulation of hypotheses}

According to the TPB, the first determinant of intention is the individual's attitude towards the intended behaviour.

(1) Managers' attitudes: perceptions of the consequences of accommodation

Managers' attitudes are influenced by the principles of diversity management, which considers the consequences of accommodation as positive. The trend in diversity management emphasises the appreciation of differences for greater organisational performance and social justice (Thomas and Ely, 1996). For some, the company creates competitive advantage by managing religious diversity (Richard, 2000). At the organisational level, the company's image and reputation can benefit from HR's marketing of the values of "tolerance" and "wealth". The company will be more attractive to recruits and will enhance creativity by recruiting employees with different points of view. At the individual level, when the organisation takes into account the differences of minorities in a nondiscriminatory approach, the impact on satisfaction, civic behaviour and turnover can be positive (Day and Schoenrade, 1997). By allowing employees to express their faith at work, management reflects an image of tolerance, which can improve 
the work environment and increase staff motivation. These findings argue for the integration of religious diversity by managers to improve performance and well-being (Hambler, 2016). However, empirical studies on diversity present conflicting results (Jehn et al., 1999). The effects of diversity are also reflected in terms of conflict (Pelled, 1996, Gebert et al., 2014, Morgan, 2004; King and Williamson, 2005, King et al., 2009), which can cover several dimensions (emotional/relational or organisational). The perception of the impact of conflict varies in strength depending on the visibility of the differences expressed (for example, the wearing of the veil (visible) and requests for leave for religious holidays (invisible)). By allowing REW, management sometimes makes an opinion visible that can create tensions within the team. An employee's religion may be the key to the employee's interpretation of managerial decisions as privileging or discrimination according to the category of identity. Allowing religious expression at work could be seen as generating a power struggle between religious minorities and the religious majority (Tsui and Gutek, 1999). By accepting REW, the company risks opening a debate and having to justify itself to certain stakeholders (RobertDemontrond and Joyeau, 2010).

Managers' attitudes reflect their beliefs about diversity management and the consequences of accommodation. These advantages and disadvantages of REW detailed in empirical studies can be anticipated by managers. Managers who work in the same organisation and face the same situation will make different decisions depending on the perceived consequences of the intention to accommodate. Therefore, we formulate the following hypothesis:

Hypothesis 1a: The perceived positive consequences of REW are positively related to the manager's intention to accommodate.

Hypothesis $1 \mathrm{~b}$ : The perceived negative consequences of REW are negatively related to the manager's intention to accommodate. 
The second determinant of intention is the manager's social (or subjective) norm, or the social pressure perceived by the manager with regard to his or her intention to accommodate.

(2) The social norm regarding the intention to accommodate

In the context of REW, religiosity has been identified in the literature as a normative belief that can influence an individual's behaviour. Religiosity refers to the intensity of a person's religious beliefs (King, 2004) and influences the perception of the organisational environment and attitudes (Krieger and Seng, 2005). Decision making encompasses a complex intuitive process involving the manager's subconscious mind, values, experience, affect and cognition (Burke and Miller, 1999). Religious belief entails values and requirements that influence this intuitive process. Interviews with managers of different faiths (Hindu, Buddhist, Catholic, Muslim) highlight the influence of their beliefs on their judgements and on how they manage their affairs (Fernando and Jackson, 2006). Different scenarios submitted to a sample of managers show that the same situation is perceived differently according to the respondent's level of religiosity (Longenecker et al., 2004). Cui et al. (2015) highlight a positive relationship between management religiosity and an active diversity policy for women and minorities. King and Williamson (2005) find a positive relationship between an employee's religiosity and his or her desire for REW to be permitted in his or her company. We assume that a similar relationship can be observed among managers in terms of the influence of their level of religiosity on their degree of accommodation of REW.

Religiosity is a subjective norm that is strongly influenced by the context of French secularism because managers develop religious belief according to the opinions of their group, and therefore of society, towards religion.

As a result, managers who express strong religiosity may more easily accept the religious expression of their colleagues, perhaps because they are more familiar with religious rites and 
culture or perhaps because they are more open to difference. As a result, the following hypotheses are proposed.

Hypothesis 2: The manager's religiosity is positively related to the manager's intention to accommodate REW.

Hypothesis 3: The manager's religiosity is positively related to (a) his or her perception of the positive consequences of REW and negatively related to (b) his or her perception of the negative consequences of REW.

The final determinant of the intent to accommodate is perceived behavioural control. In other words, the opportunities and resources available to the manager are highly dependent on his or her organisational context.

(3) Perceived behavioural control: managers' room to manoeuvre

The manager anticipates opportunities for or obstacles to his or her accommodation behaviour depending on the organisational context. In a department where staff are free to work and free to use their private smartphones, the border between professional and religious life is potentially very flexible; for example, employees can pray when they want. A manager who can provide substantial latitude in the organisation of his or her employees' tasks, the management of their working time and the organisation of their workspace can more easily allow his or her employees to live their faith at work without organisational consequences for the company. A manager of employees who are not bound by the imperatives of presence or rhythmic productive programming can more easily organise time to pray or participate in religious celebrations. In this context, the manager will perceive more room to manoeuvre (perceived behavioural control) and will be more inclined to accept the religious expression of employees. Managerial accommodation depends on the permeability of the boundaries between work and private life (Kirchmeyer, 1995, Kreiner et al. 2009, Kreiner, 2006). The permeability of living domains is largely related to the organisational flexibility of the work environment (Clark, 
2000). For Hall and Richter (1988), the flexibility of the boundaries between work and private life is a key condition for managing the reconciliation between these two areas. Flexibility refers to the organisational latitude (time, place, thoughts) available to an employee to perform his or her work (Clark, 2000). This degree of flexibility may be contingent on the mission and/or granted by management. As a result, the following hypothesis is proposed.

Hypothesis 4: The more flexible the manager perceives the organisational environment to be, the more accommodating the manager will be towards REW.

Organisational culture is a good way to describe a company's human resources philosophy (Berg, 1986). On the one hand, organisational culture constrains the way human resources are managed; on the other hand, managerial policies strengthen the organisation's culture and disseminate its values (Cameron and Freeman, 1991; Yeung et al., 1991). Managerial behaviour is therefore an essential component of organisational culture.

Under the contingency approach and organisational configuration logic, companies seek to align their human resources policy with their organisational culture (Delery and Doty, 1996). For example, in an organisation that promotes individual success and self-improvement, management (e.g., leadership style, evaluation method, compensation system) will focus on results and the achievement of objectives. This alignment aims for overall coherence to reduce conflict and increase organisational effectiveness (Cameron and Freeman, 1991). Managerial practices are therefore closely linked to organisational culture.

The manager's intention with regard to REW can be part of this organisational configuration logic and can therefore be linked to the company's culture. Depending on the company's culture, the manager will perceive more or less ability to accommodate. As a result, the following hypothesis is proposed. 
Hypothesis 5: The culture of the organisation influences the managers' intention to accommodate REW.

In summary, we propose to test the following model.

Figure 2: Proposed model of managers' intention to accommodate REW

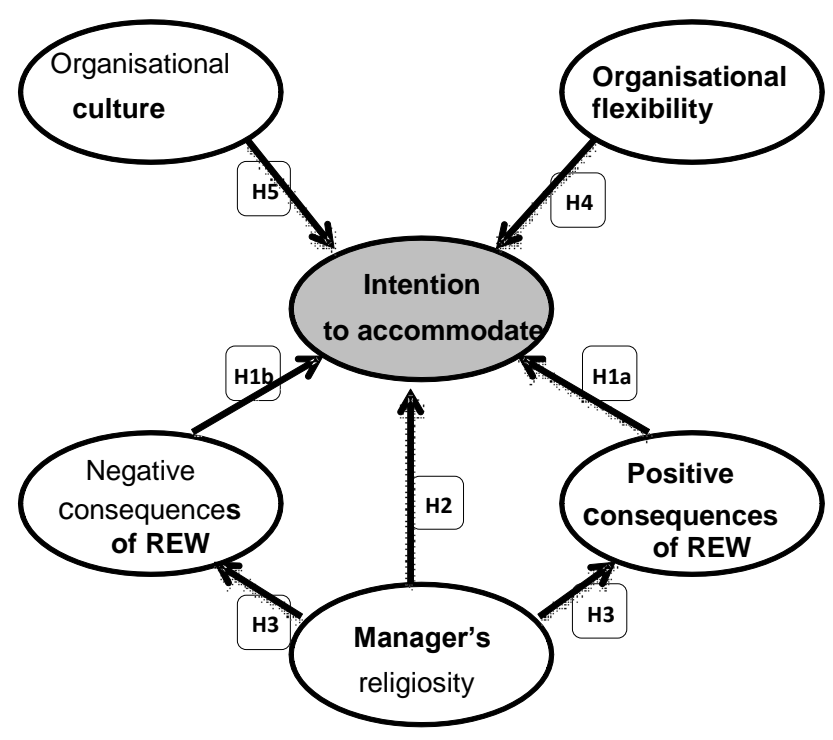

\section{Methodological Choices}

REW is a sensitive subject. It requires reflexivity on the personal convictions of the researchers, who may consciously or unconsciously influence the choice of problems, the methodology, and the variables retained in the model as well as the interpretation of the results, the discussion and the perspectives offered. As Kriger and Seng (2005) recommend, it seems appropriate to specify the profile of the authors, particularly with regard to religion and their perception of REW. One of the authors was born into a Catholic family. He is a Catholic and has an average religiosity score of 4.66 of 6 on the religiosity scale (Duke Religious Index, cf. Appendix 1). He answers "agree" to the statement, "The state must prevent religious practice at work". The other author was born into family of practising Catholics on her maternal side and anti-clerics on her paternal side whose position was a reaction to the Francoist period. She declares herself to have no religious affiliation and has an average score of 1.33 on the religiosity scale. She answers 
"somewhat agree" to the statement, "The state must prevent religious practice at work". The researchers' religiosity profiles are very different, yet their perceptions of REW in the company setting are quite similar. Data related to this political and controversial subject are difficult to access and subject to strong social desirability bias (Hennekam et al., 2018). Rao (2012) underlines the difficulty of obtaining formal acknowledgement of the negative consequences of REW perceived by the manager through interviews. Therefore, we chose a quantitative empirical validation protocol (structural equation model) combining a measurement model (the items are provided in the appendix) and a relationship model (the hypotheses). This protocol allows other researchers to perfectly replicate this study to invalidate or confirm the results and to deepen this study by adding other variables.

\section{Procedure, sample and measurement}

King and Williamson (2005) note that it is difficult to select a sample of respondents for questionnaire research on the theme of religion. This difficulty is increased when the topic is religion in the workplace. To recruit respondents for this research, contacts were made through the files of members of professional associations in Region X. Each potential respondent was contacted personally for the research via letterhead from the University of X explaining the terms of the survey. A paper questionnaire and a prestamped return envelope were attached to preserve the respondents' anonymity. This procedure (paper questionnaire, anonymity, distance from researchers) aimed to minimize social desirability bias (Butori and Parguel, 2010) and the risk of the respondent being locked into the company's official position by an incorrect or correct belief that he or she was representing his or her company with his or her answers. Ultimately, 360 questionnaires were sent to managers who supervised at least 5 people (to justify the status of manager), and 151 questionnaires were returned (return rate $42 \%$ ). The sectors can be broken down as follows: production, maintenance, and logistics, 26\%; trade and sales distribution, $8 \%$; service, consulting, banking and insurance, 27\%; health training and 
care, 19\%; computer, communication, and web services, 9\%; and catering, company services, and cleaning, $11 \%$. Table 1 presents the characteristics of the sample.

Table 1: Sample characteristics $(n=151)$

\begin{tabular}{|c|c|c|c|}
\hline Gender & & Status & \\
\hline$\overline{\text { Male }}$ & $67 \%$ & Private & $80 \%$ \\
\hline Female & $33 \%$ & Public & $7 \%$ \\
\hline$\underline{\text { Management Rate }}$ & $55^{\mathrm{a}}$ & $\begin{array}{l}\text { Private or associated with a public service } \\
\text { mission }\end{array}$ & $13 \%$ \\
\hline Age & & Education & \\
\hline 21-30 years & $7 \%$ & 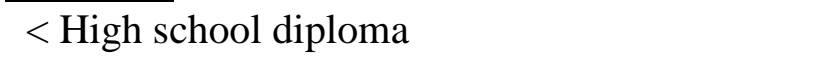 & $11 \%$ \\
\hline $31-40$ & $25 \%$ & & \\
\hline $41-50$ & $41 \%$ & Bachelor's degree & $22 \%$ \\
\hline $51-60$ & $24 \%$ & Master's degree & $58 \%$ \\
\hline $61+$ & $3 \%$ & $\mathrm{PhD}$ & $9 \%$ \\
\hline
\end{tabular}

(a) On average, respondents supervised 55 people

The administered questionnaire measured the constructs and variables by items. The details are as follows.

Table 2: Operationalisation and measurement of the variables

The measurement variables of the constructs were rated on a 6-point Likert scale from "strongly disagree" to "strongly agree" (to avoid neutral positioning).

\begin{tabular}{|c|c|c|}
\hline Constructs & Measurement variables & $\begin{array}{l}\text { Items (all items-cf. Appendix 1) formulated on a } \\
\text { 6-point Likert scale from "strongly disagree" to } \\
\text { "strongly agree" (to avoid neutral positioning) }\end{array}$ \\
\hline $\begin{array}{l}\text { Attitudes: } \\
\text { Linked to managers' } \\
\text { beliefs about REW }\end{array}$ & $\begin{array}{l}\text { Perceived } \\
\text { consequences of REW } \\
\text { (indirect measurement of } \\
\text { beliefs - Ajzen \& } \\
\text { Fishbein, 2000) } \\
\text { Def. managers' } \\
\text { judgement on the } \\
\text { disadvantages or } \\
\text { advantages of REW for } \\
\text { the company. }\end{array}$ & $\begin{array}{l}\text { Construction of the scale: } \\
30 \text { items from the literature (Gebert et al., 2014, } \\
\text { Galindo and Zannad, 2014; Cintas et al., 2013, Werr } \\
\text { et al., 2010) } \\
\text { Proofreading, saturation of measured concepts and } \\
\text { elimination of redundancy } \\
\text { Fifteen items on the advantages and } 15 \text { items on the } \\
\text { disadvantages of REW to maintain balance } \\
\text { Pretest for scale refinement to obtain } 2 \text { distinct factors } \\
\text { with high quality (quality of representation } \geq \text { at } 0.6 \text { and } \\
\text { contribution } \geq 0.7 \text { ) } \\
\text { Final scale: perceived advantage ( } 5 \text { items) and } \\
\text { perceived disadvantage ( } 6 \text { items) (see Appendix } 1 \text { ) } \\
\text { E.g., I think that REW leads to an increase in disputes } \\
\text { between employees and the organisation. } \\
\text { E.g., I think that REW leads to an improvement in the } \\
\text { social climate. }\end{array}$ \\
\hline $\begin{array}{l}\text { Subjective norms: } \\
\text { Linked to } \quad \text { social } \\
\text { context/social pressure }\end{array}$ & $\begin{array}{l}\text { Religiosity in a French } \\
\text { context steeped in } \\
\text { Christian history and } \\
\text { secularism }\end{array}$ & $\begin{array}{l}\text { Duke Religious Index }(3 \text { items) }(\text { King and } \\
\text { Williamson, 2005) from the Duke University } \\
\text { Religion Index (DUREL) (Koenig et al., 1997). } \\
\text { Unlike those of other scales, these items provide a }\end{array}$ \\
\hline
\end{tabular}




\begin{tabular}{|c|c|c|}
\hline $\begin{array}{l}\text { from the manager's } \\
\text { attitudes regarding REW }\end{array}$ & $\begin{array}{l}\text { Def. strength of the } \\
\text { religious convictions of } \\
\text { French managers }\end{array}$ & $\begin{array}{l}\text { neutral measure of faith (Pargament et al., 2000) and } \\
\text { can be administered to believers of any religion and to } \\
\text { nonbelievers (King and Crowther, 2004). } \\
\text { E.g., I try hard to carry my religion over into all other } \\
\text { dealings in life. }\end{array}$ \\
\hline $\begin{array}{l}\text { Perceived behavioural } \\
\text { control: } \\
\text { Related to the perceived } \\
\text { flexibility to } \\
\text { accommodate REW in } \\
\text { the business context }\end{array}$ & $\begin{array}{l}\text { Flexibility and } \\
\text { organisational culture: } \\
\text { Organisational } \\
\text { values/management and } \\
\text { perceived flexibility of } \\
\text { the organisational } \\
\text { structure }\end{array}$ & $\begin{array}{l}\text { Clark's Flexibility Scale (2002): } 4 \text { items } \\
\text { E.g., In my organisation, most employees do not have } \\
\text { fixed schedules. } \\
\text { Culture scale (Organisational Culture Assessment } \\
\text { Instrument-OCAI (Cameron et Quinn, 1999). Four } \\
\text { forms of culture (clan, market, bureaucracy, } \\
\text { adhocracy). Pretest: } 2 \text { dimensions stand out: the } \\
\text { adhocratic and bureaucratic profiles (quality of } \\
\text { representation }>0.6 \text { and contribution }>0.7 \text { ) } \\
\text { E.g., In my organisation, the atmosphere is } \\
\text { entrepreneurial; people take risks. }\end{array}$ \\
\hline $\begin{array}{l}\text { Intention to } \\
\text { accommodate: The } \\
\text { arrangement proposed } \\
\text { by the manager in } \\
\text { relation to the general } \\
\text { rule of the organisation }\end{array}$ & $\begin{array}{l}\text { Permeability scale } \\
\text { adapted for REW }\end{array}$ & $\begin{array}{l}\text { Kirchemeyer's (1995) permeability scale (4 items): } \\
\text { private life-professional life adapted as religious } \\
\text { life-professional life } \\
\text { E.g., the original item from the permeability scale, “ } \\
\text { organisation is flexible about employees' work } \\
\text { schedules", is adapted as "In your opinion as a } \\
\text { manager, is it preferable that.... work organisation be } \\
\text { flexible to take into account certain religious } \\
\text { demands?". }\end{array}$ \\
\hline
\end{tabular}

\section{Results}

To avoid the halo effect, items from the different scales were mixed in the questionnaire.

Collecting data via a single questionnaire can lead to common-method variance (Podsakoff, et al., 2003). To ensure the discriminant validity of the latent constructs, a principal component analysis (with varimax rotation) was first performed on all 29 items of the measurement model (Harman test). This analysis clearly showed 7 factors corresponding to the 7 variables used in this research (Appendix 1), none of which alone accounted for more than $50 \%$ of the total variance. The discriminant validity of the scales was confirmed (Fornell and Larcker protocol 1981) because the variance indicator extracted from one construct was always greater than the square of the correlations with the other constructs (rô VC $>r^{2} \mathrm{ij}$ ). In other words, each latent variable shared more variance with its measures than with the other measured latent variables. 
Table 2 presents the correlations between the variables and their means, standard deviations, internal reliability (Cronbach's alpha) and discriminant validity (Rho VC).

Table 3: Means, standard deviations, correlations, reliability, and validity

\begin{tabular}{lllllllllll}
\hline Variables (Cronbach's alpha) & $\mathrm{M}$ & $\mathrm{SD}$ & 1 & 2 & 3 & 4 & 5 & 6 & 7 & 8 \\
\hline 1-Accommodation (.92) & 2.43 & 1.10 & {$[.70]$} & & & & & & \\
2-Organisational flexibility (.74) & 3.40 & 1.07 & $.29^{* *}$ & {$[.44]$} & & & & & \\
3-Positive consequences (.88) & 2.76 & 1.11 & $.55^{* *}$ & $.19^{*}$ & {$[.62]$} & & & & \\
4-Negative consequences (.92) & 4.30 & 1.04 & $-.47^{* *}$ & $-.16^{*}$ & $-.57^{* *}$ & {$[.66]$} & & & \\
5-Bureaucratic culture (.75) & 3.91 & .90 & -.07 & $-.41^{* *}$ & -.07 & $.16^{*}$ & {$[.51]$} & & \\
6-Adhocratic culture (.75) & 4.40 & .76 & .05 & $.21^{* *}$ & .01 & .00 & -.01 & {$[.43]$} & \\
7- Religiosity (.94) & 2.50 & 1.54 & $.21^{* *}$ & $.20^{*}$ & $.26^{* *}$ & $-.26^{* *}$ & -.01 & -.01 & {$[.84]$} \\
\hline n=151, Cronbach's alpha ( ), Rho VC [ ]; p<0.01: **; P<0.05:* & & & & & \\
\hline
\end{tabular}

A structural equation model (covariance structure analysis) was used to validate the hypotheses (Amos 19 software). It tested hypotheses of causality. This protocol allowed the simultaneous testing of dependency and mediation relationships (Figure 2). The change indices calculated for each pair of variables suggest a link between corporate culture and organisational flexibility. This relationship is easily explained. Bureaucratic culture is based on a high degree of administrative formalisation and rigorous production processes. This context is not conducive to organisational flexibility, unlike adhocracy culture ("adhocracy culture is characterized by a dynamic, entrepreneurial and creative workplace"; Cameron and Quinn, 1999, p.45). The incremental (CFI, TLI), absolute (GFI, SRMR, RMSEA) and parsimonious (chi²/ddl) indices highlight the quality of the model fit: $\mathrm{Chi}^{2} / \mathrm{ddl}=1.64 ; \mathrm{GFI}=.81 ; \mathrm{SRMR}=.09 ; \mathrm{CFI}=.91$; TLI=.90; RMSEA $=.06$. The complexity of the model relative to the sample size $(n=151)$ may explain why some indices are slightly below the usual standards (Hu and Bentler, 1999). 
Figure 3: Validated model

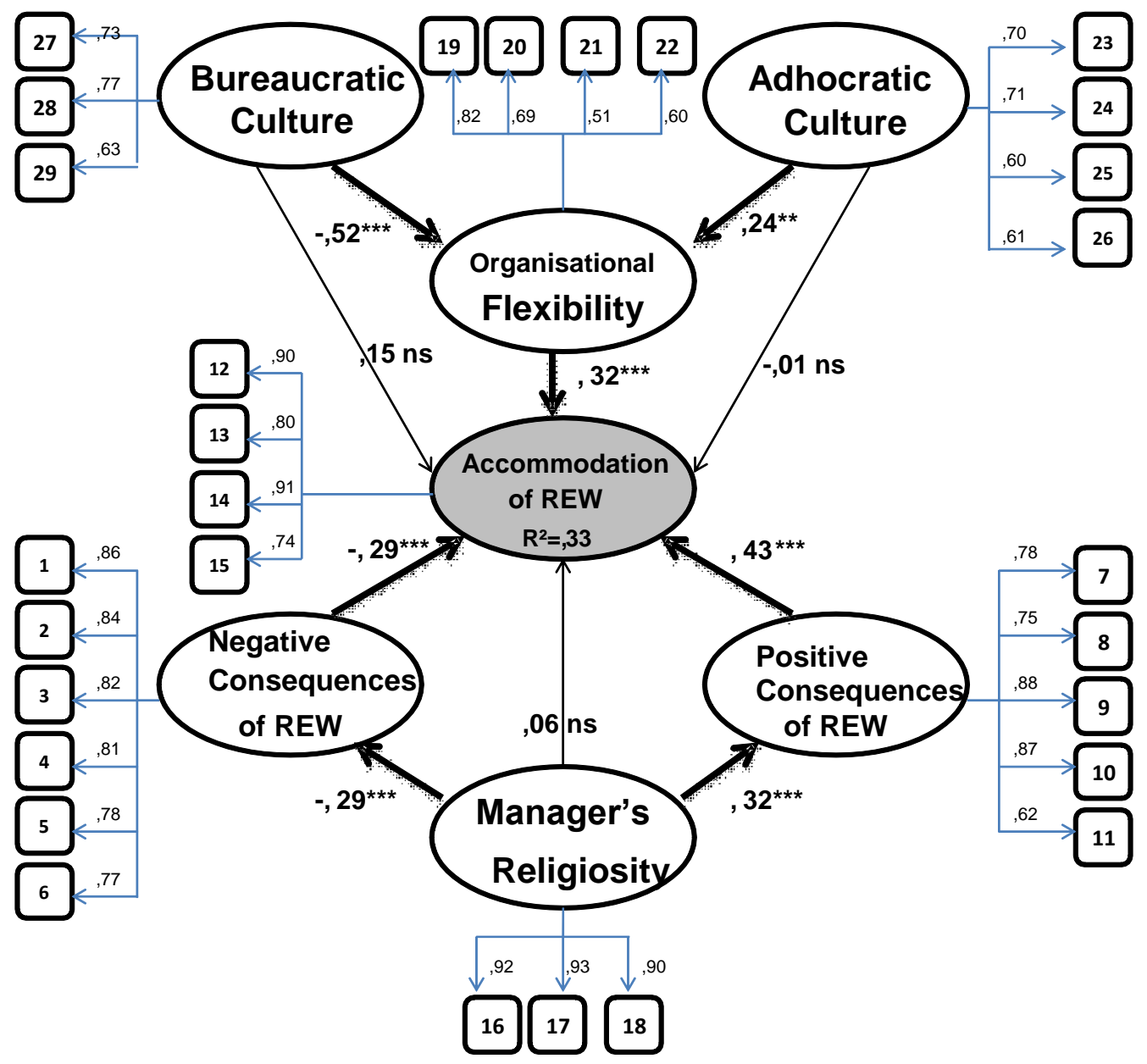

The results partially validate the hypotheses. The perceived advantages and disadvantages of REW influence the manager's intention to accommodate. The more advantages the manager perceives, the more favourable he or she is to accommodation $(\mathrm{B}=.43 ; \mathrm{P}<.001)$. Hypotheses $1 \mathrm{a}$ and $1 \mathrm{~b}$ are therefore validated. The manager's religiosity has no direct effect on the intention to accommodate $(\mathrm{B}=.06 ; \mathrm{ns})$. Thus, Hypothesis 2 is not validated. On the other hand, the manager's 
religiosity positively influences the perceived advantages $(\mathrm{B}=.32 ; \mathrm{P}<.001)$ and negatively influences the perceived disadvantages $(\mathrm{B}=-.29 ; \mathrm{P}<.001)$. Thus, Hypothesis 3 is validated. According to this result, the perceived consequences are mediating variables in the relationship between the manager's religiosity and his or her intention to accommodate (the 4 steps of Baron and Kenny's (1986) protocol confirm a complete mediating effect). Greater organisational flexibility has a positive influence on the manager's intention to accommodate $(\mathrm{B}=.32 ; \mathrm{P}<.001)$. Thus, Hypothesis 4 is validated. The corporate culture apprehended through the organisation's bureaucratic and adhocratic profiles has no effect on the intention to accommodate $(\mathrm{B}=.15$ and $\mathrm{B}=-.01$, ns). Thus, Hypothesis 5 is not validated. On the other hand, organisational flexibility is positively influenced by adhocratic culture $(\mathrm{B}=.24 ; \mathrm{P}<.01)$ and negatively influenced by bureaucratic culture $(\mathrm{B}=.52 ; \mathrm{P}<.001)$. The organisational culture (adhocracy, bureaucracy) therefore has an indirect effect on the manager's intention to accommodate REW via the organisational flexibility conditioned by the company culture.

\section{Discussion}

This research aims to explain, in the secular French context, the intention of managers to accommodate REW when they are not obligated to do so. This paper focuses on managers' accommodation stance to understand its determinants. Building on previous studies on how organisations and managers deal with religious expression, this research seeks to extend the results on managers' strategy for accommodating REW.

After presenting the theoretical implications, we will detail the practical implications, limitations and further research.

\section{Theoretical implications}

The research trend focusing on human resources management and religion, which remains neglected (Tracey, 2012, Héliot et al., 2020), makes diversity at work a subject of debate. 
Diversity management makes the issue of religious diversity a matter of struggle against discrimination but also a matter of tension and conflict (Gebert et al., 2014, Pelled, 1996; Morgan, 2004; King and Williamson, 2005; King et al., 2009). Diversity management seeks to instil in people an appreciation for difference (Michaels, 2009) - at the risk of drifting towards stigmatising HRM.

This study helps explain managers' intention to accommodate REW in a secular context when they are not obliged to do so. It provides some suggestions by proposing an explanatory model of managers' intention to accommodate REW in a French context where the legal concept of "reasonable accommodation" does not exist. The present research provides new insight by identifying two main direct factors, organisational flexibility and perceived consequences, and an indirect one, religiosity.

Through a conceptual framework integrating the TPB and diversity management, this study identifies 3 factors involved in managers' intention to accommodate: (1) managers' attitudes, (2) social norms and (3) perceived behavioural control.

(1) Attitude influences the intention to accommodate.

In accordance with the TPB, the results show that evaluation of the consequences (and therefore attitude) conditions a manager's intention to accommodate.

To understand the attitude of managers, this research measures both the perceived advantages and disadvantages of REW. The dimension of perceived disadvantages concerns problems with work organisation linked to REW (risk of litigation, marginalisation, overbidding of claims). The perceived benefits dimension focuses on the social performance of REW-related organisations. It combines benefits related to the work environment, employee satisfaction and an image of tolerance. This attitude measurement therefore explicitly refers to a manager's beliefs about the perceived consequences of his or her intention. The factor structure of the data shows that these two dimensions are not mutually exclusive but constitute two distinct 
judgements: a manager can perceive both advantages and disadvantages. This is consistent with the contradictions within diversity management studies, in which the effects of diversity are ambivalent and highly context dependent (Pelled, 1996, Gebert et al., 2014, Morgan, 2004; King and Williamson, 2005, King et al., 2009).

(2) Social norms, measured here by religiosity, influence the intention to accommodate through attitude.

This finding is in line with other research that has highlighted the effect of managers' religiosity on their investment decisions (Hilary and Hui, 2009) or management style (Kriger and Seng, 2005). In this research, the effect of religiosity is indirect. Thus, the manager's religiosity influences his or her attitude and, indirectly, his or her intention to accommodate. The more religiosity the manager displays, the more likely he or she is to think that REW has positive consequences for the organisation and, conversely, the less likely he or she is to perceive negative consequences. This result echoes one of the few studies that has examined the relationship between management's religiosity and diversity policies (Cui et al., 2015). According to Cui et al. (2015), the more religious the management is, the more diversity initiatives it develops. This research measures managers' declared religiosity, which is undoubtedly influenced by the context of French society mentioned in the preamble. The average religiosity score in this study is between 2.4 and 2.75 of 6 , depending on the item. This is not surprising, as the results of the Win-Gallup (2015) study show that France is one of the most secularized countries in the world.

Religiosity as a social norm does not validate the TPB, which suggests a direct effect of normative beliefs on intention. The results show complete mediation via attitude. This finding confirms the existence of a positive correlation between the attitudinal and normative components revealed by numerous empirical validations (Albaraccin et al., 2001). In other words, attitude corresponds with normative beliefs (Vallerand et al., 1992). The other 
explanation may derive from the fact that religiosity is not a subjective norm as defined by the TPB, namely, a social pressure perceived by the individual that causes him or her to adopt a behaviour. In this case, the manager's religiosity can be interpreted as an antecedent of attitude that is part of his or her experience, trajectory, education, and personality traits (Day 2005). The manager's religiosity can also be interpreted as a personal normative belief that, according to Budd and Spencer (1985), is common to subjective attitudes and norms, which would explain its influence on the perceived consequences of REW. The social norm to be attended to might not be "religiosity" in the French context but rather "perceived secularity". There are several representations of secularism in France. For some, neutrality consists in prohibiting religious expression; for others, neutrality consists in allowing it. Baubérot (2015, p.92) sums up this opposition with the following question: "Is it more secular to prohibit the headscarf than to tolerate it?". This perspectival tension can also be observed among French managers (Honoré, 2014). The interpretation of this principle of neutrality by the manager and therefore his or her representation of secularism is likely to constitute a powerful normative referent to explain the manager's position towards the religious fact. The representation of secularism can be interpreted as a collective norm (what is allowed according to the "secular" rules imposed by the society or organisation) and as an individual norm (what each person considers an acceptable response to his or her representation of secularism).

Further work on "social norms" and the concept of hyper- or meta-standards (Donaldson and Dunfee, 1994) would be useful to address the issue of religious diversity. These hyperstandards, or global values, are the standards observed by global organisations such as the United Nations and the International Labour Organisation. For the religious fact, human rights, equality between men and women, non-discrimination, and secularism, for example, are hyperstandards. Non-discrimination gives rise at the European level to standardisation through the concept of reasonable accommodation. 
(3) Perceived behavioural control influences the intention to accommodate through organisational flexibility

According to the results, the degree of organisational flexibility perceived by the manager, as conditioned by the company culture, influences his or her intention to accommodate. Contrary to the principle of organisational configuration, the results do not highlight an alignment between corporate culture and the management of REW. Indeed, the intention to accommodate is not directly related to an organisational culture (bureaucratic or adhocratic) but to the flexibility influenced by the culture. When an employee can easily be absent from work and organise his or her own schedule, the manager is more likely to favour accommodation. In a bureaucratic environment that is subject to compliance with rules and protocols, flexibility is reduced, and the manager is less inclined to accommodate. On the other hand, an adhocratic organisation based on innovation and teamwork provides greater flexibility, and management will view accommodation more favourably. These results confirm that the management of living domains (including the domain concerning religious practice) is largely related to the organisational flexibility of the work environment (Clark, 2000, Kirchmeyer, 1995). This result also reflects the historical evolution of the link between organisational culture and REW (Miller, 2007). In the bureaucratic culture of the 20th century, the application of strict rules and the formalisation of staff appraisal processes required employees to leave their private lives in the cloakroom. Religion was therefore relegated to the private sphere. Today, companies are moving towards a culture of experience (Miller, 2007), which is similar in many ways to adhocratic culture, making it easier for employees to express their religion. In exchange for greater availability, the company attends to the well-being of its employees and gives them more flexibility to express their identities. In this type of corporate culture, religion is more easily accepted in the workplace. Galindo (2019) distinguishes 3 postures of organisations that 
reflect their cultures according to their norm representations: imposed closed secularism (prohibition of religious expression), inclusive secularism (acceptance of all forms of religious expression), and isolated secularism (an intermediate logic allowing the implementation of accommodation in certain contexts). The culture of the organisation reflected in these postures will have an influence on managers' representations. The results of this research do not show such a direct influence of culture accommodation because they highlight organisational flexibility as a mediating variable of this relation. We propose an explanation for this influence of organisational flexibility on the accommodation decision. It seems to relate to the paradox identified in the results of the study by the Observatoire français du fait religieux (OFFRE) $(N=1100)$ : of the managers interviewed by the OFFRE (2017), three-quarters expected neutrality at work, but three-quarters also accepted religious freedom and the possibility of praying during breaks, for example. These ambivalent responses induce a specific consideration on the part of managers: how can religious freedom be allowed through managerial regulations that have no impact on the functioning of the organisation? Organisational flexibility seems to be a plausible response.

\section{Managerial implications}

Three forms of managerial implications can be proposed based on these initial results.

\section{An organisational lever for the intention to accommodate religiosity: flexibility}

For the management of REW, organisational flexibility, manifested in flexible hours and autonomy, stands out as an important element to explain the intention to accommodate. For example, an organisation can anticipate and adjust working hours during Ramadan. It can set up teleworking arrangements that give employees the autonomy to pray when they wish and to visit places of worship. This will allow workers to practise their religion on a daily basis without being beholden to a work schedule. Organisational flexibility deserves qualitative attention. 
Can there be flexibility provided by the organisation and flexibility granted by the manager? In other words, can the manager be an actor in the construction of organisational flexibility? If a company wishes to develop a utilitarian strategy (Morgan, 2004) to take advantage of REW, it can focus on this organisational variable by strengthening or reducing this organisational flexibility. The establishment of a culture that values "work and life" (Putnam et al., 2014) and the emergence of Third Places as a new form of work organisation that integrates the different areas of life promote this organisational flexibility.

\section{Tools to increase the nuance of managerial decision making}

The results of this research can contribute to approaches to drafting company guidelines on REW for managers. Such guidelines currently present scenarios using certain decision criteria that can be grouped into two broad families. The first concerns the protection of individuals (protection against proselytism, respect for occupational safety conditions, respect for hygiene conditions), and the second concerns the proper functioning of the company (employees' ability to fulfil their mission, respect for work organisation, respect for commercial interests, respect for the safety of installations). The results of this study reveal another family of criteria specific to managers: the "perceived organisational flexibility and religiosity" involved in decisionmaking mechanisms. Even when managers use the same company guidelines as a decisionmaking tool, their intention to accommodate will depend on their religiosity (subjective norm) and perceived organisational flexibility (perceived behavioural control). In Cui et al. (2015), the discussion of the results reveals the importance of social norms in the sense of hypernorms (religiosity) and undoubtedly of secularism, non-discrimination, and gender equality in the decision-making process on accommodation. These inclusive norms should therefore be handled with care in the various guidelines that have been developed.

2. A risk prevention policy through inclusive neutrality? 
The results of this study may help organisations anticipate the risks associated with REW. The perceived negative consequences of REW are evaluated via 6 items belonging to the same construct. In the minds of managers, organisational problems are associated with risks of marginalisation of employees and more demands and interpersonal tensions between colleagues. REW presents perceived risks by sometimes making visible an initially invisible criterion of distinction (Clair et al., 2005). In the context of French secularism, where religion is relegated to the private or even intimate sphere, reactions to the visibility of REW can be translated into social tensions. Overall, the score of managers' intention to accommodate REW is low (2.6 of 6).

To mitigate this risk, managers mobilise two strategies to make REW invisible.

First, they favour the common-ground strategy (Hennekam et al., 2018). This strategy consists "of the creation of a strong company culture that everyone could relate to, overruling as such individual differences" (ibid, p.756). Through this strategy, organisations can propose an inclusive accommodation framework or a practice that makes REW invisible. For example, in response to requests for religious meals, some organisations offer a buffet where all food practices (regardless of whether they are related to religion) can be satisfied without revealing the religious orientation of the staff. This strategy based on common ground makes it possible to create a meta-culture that brings together all differences.

Second, some managers allow religious practices in the workplace as long as they are made invisible to other employees. For example, a human resources director in the automotive industry allows the display of a prayer at the workstation of an operator who is isolated in the production process. Only this operator, at his or her workstation, can benefit from this REW. These minor adjustments are part of the manager's room to manoeuvre. Such an approach can be easily implemented, as most requests for religious accommodation are for minor issues only (Galindo and Zannad, 2012). 
This research extends studies on diversity management by revealing a paradox or ambivalence in diversity management: managers wish to manage visible religious differences (e.g., eating practices, prayer) by making them invisible (e.g., inclusive practices, inclusive neutrality). This nuances the ideological paradigm of diversity management. A first systematic review published very recently on the subject of religious identity (Héliot et al.,2020) makes a major contribution to the field by attempting to explain how, when and with what consequences religious identity is compatible or incompatible with the workplace identity. It provides perspectives on the integration and role of faith at work. The aim is to improve the "fit" between religious identity and identity at work to move towards more inclusive organisations and avoid conflict. What if, in France, this were partly achieved through the "invisible" management of religious diversity by managers?

These results present opportunities for research in the same vein to discover possibilities for organising work situations that promote religious expression while preventing potential dysfunction or conflict (Héliot et al., 2020).

\section{Limitations and future research}

We acknowledge several limitations in our research. First, understanding and explaining managers' intention to accommodate REW requires further quantitative and, above all, qualitative research. Our sample size is relatively small. However, we followed the same protocol used in hard science, and the tests of significance adapted to the sample size highlight the replicability of the study. Data mining was used to verify the stable structure of the data. We recommend that a qualitative study with interviews and photoelicitation (Harper, 2002) be performed to extend this first study of managers' intention to accommodate religious beliefs. Indeed, the complexity of managerial postures requires an in-depth understanding of managers' attitudes and behaviour with regard to religion. How do managers implement a common-ground 
strategy and create unity? A qualitative study would make it possible to capture complex situations to reveal this management of religious diversity. Is the desire to make arrangements invisible with a view to inclusive neutrality specific to France, or can it be generalised to managers in other countries? Does the intention to accommodate not essentially depend on the manager-employee relationship dynamic? The management of otherness and the dynamics of the relation between the managerial posture and employees' posture could offer a new way of apprehending the religious fact in companies within the legal framework under construction. This would make it possible to identify the conditions (concrete contexts, postures and dynamics) that can enable the implementation of inclusion.

Second, social norms are a determining factor in understanding managers' postures. Depending on the country and context, it would be interesting to understand which norms play a major role: Religiosity? Secularism? Non-discrimination? Gender equality? A mix? Our research highlights the need for deeper exploration to address this question. The social norm to be attended to might not be "religiosity" in the French context but "perceived secularity". The development of a scale for measuring secularity could be an interesting research direction.

Third, research on the ethics of managerial conduct should be conducted. This snapshot does not allow us to understand the dynamics of diversity management over time. In other words, managers learn as they encounter these situations. How does a manager go from a neutral or even prohibitionary stance to an open stance through the experience of the REW situations? In this context, it would be interesting to explore another line of research on managerial moral courage (Sekerka et al., 2009; Harbour et al., 2014). Managers need to develop this skill to respond as ethically as possible to the competing demands of freedom of religious expression and the preservation of equality (universal principle of secularism). This path of conduct oriented towards "fairness" is linked to the ethical dimension of decisions and constitutes a research perspective focused on the notion of "fair decisions and conduct". One of the 
favourable conditions for the search for fairness lies partly in openness to the other. This research raises questions about the relationship with the other and ethical managerial conduct.

\section{REFERENCES}

Adam, I. and Réa A. (2010). La diversité culturelle sur le lieu de travail-pratiques

d'aménagement raisonnables, Institute for european Studies- Migration and diversity cluster Vrije Universiteit Brussel, Septembre.

Rapport d'étude :http://www.diversite.be/?action=publicatie_detail\&id=126\&thema=6

Ajzen, I. (1987). Attitudes, traits and actions: Dispositional prediction of behavior in personality and social psychology. Advances in Experimental Social Psychology, 20, pp.1-63.

Ajzen, I. (1991). The theory of planned behavior. Organizational Behavior and Human Decision Processes, 50, pp.179-211.

Ajzen, I., and Fishbein, M. (2000). Attitudes and the attitude-behavior relation: Reasoned and automatic process. European Reviewof Social Psychology, 11, pp.1-33.

Albaraccin, D., Johnson, B.T., Fishbein, M., and Mullerleile, P.A. (2001). Theories of reasoned action and planned behavior as models of condom use: A meta-analysis. Psychological Bulletin, 127, pp.142-161.

Ang, M. C., Ramayah, T., \& Amin, H. (2015). A theory of planned behavior perspective on hiring Malaysians with disabilities. Equality, Diversity and Inclusion: An International Journal.

Araten-Bergman, T. (2016). Managers' hiring intentions and the actual hiring of qualified workers with disabilities. The International Journal of Human Resource Management, 27(14), 1510-1530.

Bader, V., Alidadi, K., and Vermeulen, F. (2013). Religious diversity and reasonable accommodation in the workplace in six European countries: An introduction. International journal of discrimination and the law, 13(2-3), pp. 54-82.

Baron, R.M. and Kenny, D.A. (1986). The Moderator-Mediator Variable Distinction in Social psychological Research: Conceptual, Strategic, and Statistical Considerations, Journal of Personality and Social Psychology, 51(6), pp. 1173-1182.

Baubérot J. (2015), Les sept laïcités françaises : le modèle français de laïcité n'existe pas, Editions de la Maison des Sciences de l'Homme. 
Berg, P.O. (1986). Symbolic management of human resources, Human Resource Management, 25 (4), pp. 557-579.

Benn Michaels, W. (2009). La diversité contre l'égalité. Lectures, Les livres.

Bowen, John R. (2004). Does French Islam Have Borders? Dilemmas of Domestication in a Global Religious Field. American Anthropologist, 106, pp. 43-55.

Budd, R.J., and Spencer, C.P. (1985). Exploring the role of personal normative beliefs in the theory of reasoned action: The problem of discriminating between alternative path models. European Journal of Social Psychology, 15, pp. 219-313.

Burke, L. and Miller, M. (1999). Taking the mystery out of intuitive decision making, The Academy of Management Executive, 13(4), pp. 91-100.

Butori, R. and Parguel, B. (2010). Les biais de réponse - Impact du mode de collecte des données et de l'attractivité de l'enquêteur, Actes du 26 ème congrès de l'association Française du marketing, Le Mans.

Cameron, K.S and Freeman, S.J (1991). Cultural congruence, Strength, and Type: Relationships to effectiveness, Research in organizational Change and Development, 5, pp. 2358.

Cameron, K. S. and Quinn, R. E. (1999). Diagnosing and changing organizational culture : Based on the competing values framework, The Jossey-Bass Business \& Management series, $1-234$.

Cash, K. C. and Gray, G. R. (2000). A framework for accommodating religion and spirituality in the workplace. The Academy of Management Executive, 14(3), pp. 124-133.

Chuang, Shuang-Shii, Kun-Shiang Chen, and Ming-Tien Tsai. (2015). Exploring the antecedents that influence middle management employees' knowledge-sharing intentions in the context of total quality management implementations. Total Quality Management \& Business Excellence, 26(1-2), pp. 108-122.

Cintas, C. Gosse, B. and Vatteville, E. (2013). Religious identity: a new dimension of HRM? A French view. Employee Relations, 35(6), pp. 576-592.

Clark, S. C. (2000). Work/family border theory: A new theory of work/family balance. Human relations, 53(6), pp.747-770.

Clark, C. (2002). Communicating across the work/home border. Community, Work \& Family, 5(1), pp.23-48.

Clair, J. A., Beatty, J. E.and MacLean, T. L. (2005). Out of sight but not out of mind: Managing invisible social identities in the workplace. Academy of Management Review, 30(1), pp. 78-95. 
Conseil de l'Europe (2000), Directive 2000/78/CE du Conseil du 27 novembre 2000 portant création d'un cadre général en faveur de l'égalité de traitement en matière d'emploi et de travail.

Cui, J., Jo, H. Na, H. and Velasquez, M. (2015). Workforce Diversity and Religiosity, Journal of Business Ethics, 128, pp. 743-767.

Dawkins, C.E. and Frass, J.W. (2005). Decision of union workers to participate in employee involvement: An application of the theory of planned behavior. Employee Relations, 27(5), pp. $511-531$.

Day, N.E (2005). Religion in the Workplace: Correlates and Consequences of Individual Behavior, Journal of Management, Spirituality \& Religion, 2(1), pp.104-135.

Day, N E. and Schoenrade, P. (1997). Staying in the closet versus coming out: Relationships between communication about sexual orientation and work attitudes. Personnel Psychology, 50(1), pp. 147-163.

Delery, J.E and Doty, D.H. (1996). Modes of theorizing in strategic human resource management: Tests of Universalistic, contingency, and configurational performance predictions, Academy of Management Journal, 39(4), pp. 802-835.

Donaldson, T., \& Dunfee, T. W. (1994). Toward a unified conception of business ethics: Integrative social contracts theory. Academy of management review, 19(2), 252-284.Fernando, M. and Jackson B. (2006). The influence of religion-based workplace spirituality on business leaders' decisionmaking: An inter-faith study. Journal of Management \& Organization, 12(1), pp.23-39.

Fornell, C. and Larcker, D. (1981). Evaluating structural equation models with unobservable variable and measurement error. Journal of Marketing Research, 18(1), pp. 39-50.

Galindo G. and Surply J. (2010) ‘ Quelles régulations du fait religieux en entreprise ?', Revue internationale de psychosociologie, hiver, p.29-54.

Galindo G. and Zannad H. (2012), “Quelques clés pour mieux gérer le fait religieux dans les Entreprises”, Barth, I. (Ed.), Management et Religion, Editions EMS, Paris, pp.61-82.

Galindo, G. and Zannad, H. (2014). Les grandes entreprises françaises et la religion. RIMHE: Revue Interdisciplinaire Management, Homme \& Entreprise, (4), pp. 40-53.

Galindo G. (2019), La laïcité, un principe de plus en plus complexe à manier pour les entreprises, octobre, The conversation. https://theconversation.com/la-la-cite-un-principe-de-plus-en-pluscomplexe-a-manier-pour-les-entreprises-125949

Gebert, D., Boerner, S., Kearney, E., King, Jr J. E., Zhang, K. and Song, L.J., (2014). Expressing religious identities in the workplace: analyzing a neglected diversity dimension, Human Relations, 67(5), pp.543-563. 
Giger, J. C. (2008). Examen critique du caractère prédictif, causal et falsifiable de deux théories de la relation attitude-comportement: la théorie de l'action raisonnée et la théorie du comportement planifié. L'année Psychologique, 108(1), pp. 107-131.

Gundolf, K., and Filser, M. (2013). Management research and religion: A citation analysis. Journal of Business Ethics, 112(1), pp. 177-185.

Hall, D.T and Richter, J. (1988). Balancing work life and home life: what can organizations do to help? Academy of Management Executive, 2, pp. 213-223.

Hambler, A. (2016). Managing workplace religious expression within the legal constraints. Employee Relations, 38(3), pp. 406-419.

Harbour, M., \& Kisfalvi, V. (2014). In the eye of the beholder: An exploration of managerial courage. Journal of Business Ethics, 119(4), 493-515.

Héliot, Y.F., Gleibs, I. H., Coyle, A., Rousseau, D., and Rojon, C. (2020). Religious identity in the workplace A systematic review, research agenda, and practical implications. Human Resource Management, 59 (2) pp. 153-173

Hennekam, S., Peterson, J., Tahssain-Gay, L., and Dumazert, J. P. (2018). Managing religious diversity in secular organizations in France. Employee Relations, 40(5), pp. 746-761.

Hilary, G. and Hui, K.W. (2009). Does religion matter in corporate decision making in America, Journal of Financial Economics, 93, pp. 455-473.

Hitt, M. A. and Tyler, B.B. (1991). Strategic decision models: Integrating different perspectives. Strategic management journal, 12(5), pp. 327-351.

Honoré, L. (2014). Le management à l'épreuve de la religion. RIMHE: Revue Interdisciplinaire Management, Homme \& Entreprise, 4, pp.54-67

Honoré L., (2019) Religion au travail : croire au dialogue : Baromètre du Fait Religieux en Entreprise 2019, Paris, Institut Montaigne, novembre 2019, 178 p.

$\mathrm{Hu}, \mathrm{L}$. and Bentler, P. (1999). Cutoff criteria for fit indexes in covariance structure analysis: Conventional criteria versus new alternatives. Structural equation modeling: a multidisciplinary journal, 6(1), pp. 1-55.

Hunter-Henin, M. (2015). Religion, children and employment: the baby loup case, International \& Comparative Law Quarterly, 64(3), p. 717-731.

Jehn, K. A., Northcraft, G. B. and Neale, M.A. (1999). Why differences make a difference: A field study of diversity, conflict and performance in workgroups. Administrative science quarterly, 44(4), pp. 741-763. 
Killian, C. (2007). From a community of believers to an Islam of the heart: "conspicuous" symbols, Muslim practices, and the privatization of religion in France. Sociology of Religion, 68(3), pp.305-320.

King, J. E., and Crowther, M. R. (2004). The measurement of religiosity and spirituality: Examples and issues from psychology. Journal of Organizational Change Management, 17(1), pp. 83-101.

King, J.E. and Williamson, I.O. (2005). Workplace Religious Expression, Religiosity and Job Satisfaction: clarifying a Relationship. Journal of Management, Spirituality and Religion, 2(2), pp. 173-198.

King, J.E. Jr. (2008). (Dis)Missing the obvious- Will Mainstream Management Research Ever Take Religion Seriously? Journal of Management Inquiry, 17(3), pp. 214-224.

King, Jr, J. E., Bell, M. and Lawrence, E. (2009). Religion as an aspect of workplace diversity: an examination of the US context and a call for international research. Journal of Management, Spirituality and Religion, 6(1), pp.43-57.

Kirchmeyer, C. (1995). Managing the work-nonwork boundary: an assessment of organizational responses. Human Relation, 48(5), pp. 515-536.

Koenig, H.G, Parkerson, G.R. and Meador, K.G. (1997). Religion index for psychiatric research: a 5 item measure for the use in health outcome studies. American Journal of Psychiatry, 154(6), pp. 885-897.

Konopaske, R., Chet, R. and John M. Ivancevich (2009). Managerial willingness to assume traveling, short-term and long-term global assignments. Management International Review, 49(3), pp. 359-387.

Kreiner, G. E. (2006). Consequences of work-home segmentation or integration: A personenvironment fit perspective. Journal of Organizational Behavior, 27, pp. 485-507.

Kreiner, G. E., Hollensbe, E. C., and Sheep, M. L. (2009). Balancing borders and bridges: Negotiating the work-home interface via boundary work tactics. Academy of Management Journal, 52, pp. 704-730.

Kriger, M. and Seng, Y. (2005). Leadership with inner meaning: A contingency theory of leadership based on the worldviews of five religions. Leadership Quarterly, 16(5), pp. 771806.

Livari, J. and Huisman, M. (2007). The relationship between organizational culture and the deployment of systems development methodologies. Mis Quarterly, 31(1), pp. 35-58. 
Longenecker, J.G. McKinney, J.A and Moore, C.W. (2004). Religious intensity, evangelical Christianity, and business ethics: An empirical study. Journal of Business Ethics, 55, pp. 37386.

Ludlum R. (2016). Be careful what you might suspect : Religion and accommodation in the workplace. Labor Law Journa, summer, pp. 375-382.

Mazumdar et Mazumdar, 2005, "How Organizations Interface with Religion : A Typology”, Journal of Management, Spirituality and Religion, 2:2, p.199-220.

McCarthy, A., Darcy, C. and Grady, G. (2010). Work-life balance policy and practice: Understanding line manager attitudes and behaviors. Human Resource Management Review, 20(2), pp.158-167.

McClay W. M. (2001). Two Concepts of Secularism. Journal of Policy History, 13, pp. 47-72. Miller, D. W. (2007). God at work: The history and promise of the faith at work movement. Oxford University Press.

Morgan, J. F. (2004). How Should Business Responds to a More Religious Workplace? SAM Advanced Management Journal, 69(4), pp. 11-19.

Observatoire du Fait Religieux en Entreprise (2015). (2016). (2017). (2018). Le travail, l'entreprise et la question religieuse: étude, Institut Randstad/OFRE.

Pargament K, Koenig H. and Perez L. (2000). The Many methods of religious coping: Development and initial validation of the RCOPE. Journal of Clinical Psychology, 56(4), pp. $519-543$.

Pena-Ruiz H. (2004). Laïcité : principes et enjeux actuels. Cités, Paris, PUF.

Pelled, L.H. (1996). Demographic Diversity, Conflict, and Work Group Outcome: an intervening process Theory. Organization Science, 7(6), pp. 615-631.

Pelletier, D. (2014). Les religions en France depuis la fin de la seconde guerre mondiale, crise ou recomposition? In Alain Tallon \& al. Histoire du christianisme en France (pp. 423-438). Armand Colin.

Podsakoff, MacKenzie, Lee and Podsakoff (2003). Common method in behavioral research: A critical review of the literature and recommended remedies. Journal of applied Psychology, 88 (5), pp. 879-903.

Putnam, L. L., Myers, K. K. and Gailliard, B. M. (2014). Examining the tensions in workplace flexibility and exploring options for new directions. Human Relations, 67 (4), pp. 413-440.

Rao, A. (2012). Managing diversity: Impact of religion in the Indian workplace. Journal of World Business, 47, pp. 232-239.

Richard, O.C. (2000). Racial Diversity, Business Strategy, and Firm Performance : A 
Resource-Based View. Academy of Management Journal, 43 (2), pp. 164-177.

Robert-Demontrond, P. et Joyeau, A. (2010). La performance des politiques de diversité en question : une étude des représentations des acteurs. Management \& Avenir, 31, pp.71-91.

Sekerka, L. E., Bagozzi, R. P., \& Charnigo, R. (2009). Facing ethical challenges in the workplace: Conceptualizing and measuring professional moral courage. Journal of Business Ethics, 89(4), 565.

Thomas, D.A. and Ely R.J. (1996). Making differences matter, a new paradigm for managing diversity. Harvard Business Review, sept-oct, pp. 1-13.

Tracey, P. (2012). Religion and organization: A critical review of current trends and future directions. The Academy of Management Annals, 6(1), pp. 87-134.

Tsui, A. S. and Gutek, B. A. (1999). Demographic differences in organizations: Current research and future directions. Lexington Books.

Vallerand, R.J., Deshaies, P., Cuerrier, J.P., Pelletier, L.G. and Mongeau, C. (1992). Ajzen and Fishbein's theory of reasoned action as applied to moral behavior: A confirmatory analysis. Journal of Personality and Social Psychology, 62, pp. 98-109.

Yeung, A.K.O, Brockbank, J.W and Ulrich, D.O (1991). Organizational culture and Human Resource Practices: An empirical assessment, Research in organizational Change and Development, 5, pp. 59-81.

Weer C.H, Greenhaus J. H and Linnehan F. (2010). Commitment to nonwork roles and job performance : Enrichment and conflict perspectives. Journal of Vocational Behavior, 76, pp. 306-316. 


\begin{tabular}{|c|c|c|c|c|c|c|c|c|c|c|c|}
\hline \multicolumn{9}{|c|}{ Appendix 1 : component matrix (scales) } & \multirow{3}{*}{\multicolumn{2}{|c|}{\begin{tabular}{c|c}
$\begin{array}{c}\text { quality } \\
\text { extraction }\end{array}$ & Av.
\end{tabular}}} & \multirow[b]{3}{*}{ Dev. } \\
\hline & & \multicolumn{7}{|c|}{ Components } & & & \\
\hline $\mathrm{n}^{\circ}$ & Items & $\mathrm{F} 1$ & F2 & F3 & F4 & F5 & F6 & F7 & & & \\
\hline \multicolumn{12}{|c|}{ Negative consequences of religious expression at work (I believe that religious expression in the workplace leads to : ) } \\
\hline 1 & The increase in disputes between employees and the organization & ,829 &,- 151 &,- 183 &,- 108 &,- 058 & 071 & 190 & 0,80 & 4,28 & 1,23 \\
\hline 2 & The marginalisation of certain employees in relation to the corpo rate culture & ,827 &,- 281 &,- 084 &,- 046 &,- 024 &,- 015 & 055 & 0,78 & 4,34 & 1,22 \\
\hline 3 & A risk of outbidding for all kinds of claims & ,826 &,- 193 &,- 152 &,- 105 & 023 & ,017 &,- 069 & 0,76 & 4,49 & 1,28 \\
\hline 4 & Interpersonal tensions between co-wo rkers & ,811 &,- 164 &,- 124 &,- 069 &,- 107 &, 001 & 033 & 0,72 & 4,48 & 1,22 \\
\hline 5 & Problems of work organisation &, 767 &,- 112 &,- 288 &,- 119 &, 042 &,- 005 &, 012 & 0,70 & 4,27 & 1,22 \\
\hline 6 & Stressful difficulties & ,748 &,- 261 &,- 133 &,- 072 &,- 095 &,- 018 &, 130 & 0,68 & 3,96 & 1,27 \\
\hline
\end{tabular}

Positive consequences of Religious Expression at work (I believe that religious expression in the workplace leads to :)

\begin{tabular}{|c|l|}
\hline 7 & Employee satisfaction \\
\hline 8 & Better company performance \\
\hline 9 & Improve the social climate \\
\hline 10 & Well-being of employees \\
\hline 11 & A more tolerant organisation \\
\hline Accommodation ( In your opinion as a manager, it is preferable that :) \\
\hline 12 & Work organisation be flexible to take into account certain religious demands \\
\hline 13 & Organisation offers facilities to take into account certain religious demands \\
\hline 14 & Organisation is flexible to facilitate the religious practice of employees \\
\hline 15 & Work organisation adapts to religious rites and practices \\
\hline
\end{tabular}

\begin{tabular}{|c|c|c|c|c|c|c|c|c|c|}
\hline -226 - & ,790 & 209, & 116 &,- 055 & ,031 &,- 095 & 0,75 & 2,94 & 1,41 \\
\hline -299 & ,758 & 209 &,- 020 & 037, &,- 071 & ,034 & 0,72 & 2,45 & 1,16 \\
\hline -,374 & ,754 & 202 & ,088 & 150, & 039 & ,029 & 0,78 & 2,72 & 1,25 \\
\hline -,275 & ,742 & 284 & ,080, & 180, &,- 013 & 091 & 0,75 & 2,97 & 1,30 \\
\hline 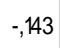 & ,647 & 202 & 302 &,- 055 &,- 039 & -193 & 0,61 & 2,97 & 1,37 \\
\hline (231 - -231 & 165, & ,853 & , 137, & 161 & ,079, & -057 & 0,86 & 2,64 & 1,26 \\
\hline 年, & ,239 & ,842 &,- 008 & 139 &,- 043 & ,054 & 0,82 & 2,56 & 1,24 \\
\hline -290-, & 254, & ,817 & 047, & 105, & ,021 & \begin{tabular}{|l|l|} 
& -002 \\
\end{tabular} & 0,83 & 2,44 & 1,22 \\
\hline 207-, & 259 & ,778 & ,067 & ,067 & ,038 &,- 034 & 0,73 & 2,10 & 1,15 \\
\hline 123,-, & 109, & ,063, & 923 & 126 & ,006 &,- 031 & 0,90 & 2,42 & 1,65 \\
\hline 108,- & 145 & ,076, & 923, & 091 &,- 030 & 037 & 0,90 & 2,36 & 1,54 \\
\hline 年, & 080 & ,045, & ,912 & ,095, & -,030 & 051 & 0,87 & 2,75 & 1,71 \\
\hline -066 & 169, & 178 & ,040 & ,783 & 103 & -155 & 0,71 & 3,18 & 1,48 \\
\hline -,092 & ,087, & ,068 & ,042 & ,768 & $-0,019$ &,- 137 & 0,63 & 2,93 & 1,72 \\
\hline ,099 & -114 & ,040 & 087, & ,671 & 114 & $-0,091$ & 0,50 & 4,16 & 1,24 \\
\hline 作, - & ,040, & 112 & , 133, & 612 & 138, & -198 & 0,50 & 3,37 & 1,24 \\
\hline ,085, &,- 163 &,- 075 &,- 097 & 035, & ,793 &,- 054 & 0,68 & 4,36 & 1,06 \\
\hline ,085, & 141 & ,044 & 032, & ,060 & ,791 & 170 & 0,69 & 4,70 & 0,96 \\
\hline -,028 & -,215 & 145, &,- 034 & 078, & ,700 & 038 & 0,57 & 4,91 & 0,93 \\
\hline 位, & 239, &,- 043 & ,052 & 177, & 684 &,- 098 & 0,59 & 3,66 & 1,12 \\
\hline ,023, & 年, & ,027, &,- 030 & - 213 & ,003 & ,785 & 0,68 & 3,93 & 1,06 \\
\hline ,064, & ,047, & ,022 & 028, &,- 280 & - & ,776 & 0,72 & 3,36 & 1,22 \\
\hline 142, &,- 006 &,- 069 & ,061 &,- 107 & 234, & ,772 & 0,69 & 4,47 & 1,02 \\
\hline
\end{tabular}


